\title{
Air quality index from charcoal production sites, carboxyheamoglobin and lung function among occupationally exposed charcoal workers in South Western Nigeria
}

\author{
O. O. Olujimi ${ }^{1,2^{*}}$, G. R. E. E. Ana ${ }^{2}$, O. O. Ogunseye ${ }^{2}$ and V. T. Fabunmi ${ }^{2}$
}

${ }^{*}$ Correspondence:

olujimio@funaab.edu.ng;

olujimiolusoji@yahoo.com

${ }^{1}$ Department

of Environmental

Management and Toxicology,

Federal University

of Agriculture, Abeokuta,

Ogun State, Nigeria

Full list of author information

is available at the end of the

article

\begin{abstract}
Charcoal production is often accompanied with gaseous and particulate emission into the atmosphere and occupationally exposed workers could be affected. This cross sectional comparative study was carried out to assess the levels of carbon monoxide (CO), carbon dioxide $\left(\mathrm{CO}_{2}\right)$, sulphur dioxide $\left(\mathrm{SO}_{2}\right)$, nitrogen dioxide $\left(\mathrm{NO}_{2}\right)$ and particulate matter $\left(\mathrm{PM}_{2.5}\right)$ generated during the phases of charcoal production and their relationship with certain biomarkers among charcoal workers (subjects) and non-charcoal workers (controls) such as carboxyhaemoglobin ( $\mathrm{COHb}$ ), forced expiratory volume in the first second of expiration $\left(F E V_{1}\right)$, peak expiratory flow rate (PEFR) and body mass index (BMI) in Igbo-Ora, Oyo State and Alabata, Ogun State, which are two of the major hubs of charcoal production in South Western Nigeria. Four communities in Igbo-Ora and six communities in Alabata were purposively selected and levels of pollutant gases were assessed using appropriate gas meters, $\mathrm{PM}_{2.5}$ was assessed with Thermo Scientific MIE pDR-1500, FEV 1 and PEFR were measured with Piko-1 spirometer while $\mathrm{COHb}$ was assessed using non-invasive pulse CO-oximeter ( $\operatorname{Rad} 57$ ). Data were statistically analyzed and results were compared with recommended guidelines. The mean $F_{1}$, PEFR, COHb and BMI for subjects and controls were $2.35 \pm 0.73$ and $2.69 \pm 0.56$, $253.72 \pm 103.45$ and $330.02 \pm 94.61(p<0.01), 13.28 \pm 3.91$ and $8.50 \pm 3.68(p<0.01)$ and $21.97 \pm 2.19$ and $23.36 \pm 3.74(p<0.05)$ respectively. There was a statistically significant difference between actual and expected values of FEV $(p<0.01)$ and PEFR $(p<0.01)$ among charcoal workers. There existed a positive correlation between $C O$ and $\mathrm{COHb}$ while $\mathrm{FEV}_{1}$ and PEFR correlated negatively with $\mathrm{PM}_{2.5}$. The study showed that charcoal workers are exposed to high levels of $\mathrm{CO}$ and $\mathrm{PM}_{2.5}$, contributing to lowered respiratory functions for $\mathrm{FEV}_{1}$ and PEFR and high levels of $\mathrm{COHb}$ compared to the control group. Routine respiratory and carboxyheamoglobin assessment of persons involved in charcoal production is also recommended.
\end{abstract}

Keywords: Gases emission, Air quality index, Lung function, Carboxyheamoglobin, Charcoal production, Nigeria

\section{Background}

Emissions from biomass burning is known to generate a large number of air pollutants e.g. respirable particulate matter (PM), carbon monoxide (CO), nitrogen oxides (NOx),

(c) 2016 The Author(s). This article is distributed under the terms of the Creative Commons Attribution 4.0 International License (http://creativecommons.org/licenses/by/4.0/), which permits unrestricted use, distribution, and reproduction in any medium, provided you give appropriate credit to the original author(s) and the source, provide a link to the Creative Commons license, and indicate if changes were made. 
sulphur oxides (SOx), formaldehyde, benzene, 1, 3-butadiene, polycyclic aromatic hydrocarbon (PAH) including carcinogens such as benzo[a]pyrene and other toxic organic compounds that can damage human health (Ezzati et al. 2000; Mishra and Retherford 2007). Exposure to air pollutants has been linked with pneumonia, reduced birth weight, acute respiratory infection (ARI) and early mortality in children while adults experience chronic obstructive pulmonary disease (COPD), chronic bronchitis (Bruce et al. 2000; Mishra and Retherford 2007; Fullerton et al. 2009; Po et al. 2011). Other health effects include lung cancer, asthma, cancer of the nasopharynx and larynx, tuberculosis, perinatal conditions, diseases of the eye e.g. cataract and blindness (Bruce et al. 2000; Ezzati and Kammen 2001a, b; Barone-Adesi et al. 2012; Edokpa and Ikelegbe 2012; Kurmi et al. 2012).

There has been major shift from the use of petroleum products and electricity due to high cost and epileptic power supply to the use of charcoal in both the rural and urban centers in Nigeria. This shift have resulted in high demand for charcoal with attendant environmental and health effects. Over $90 \%$ of studies on charcoal production in Nigeria have mainly focused on the economic benefit of the production vis-à-vis poverty alleviation of the rural populace involved in charcoal production and influence of wood species on the properties of charcoal (Ogunsanwo et al. 2007; Tunde et al. 2013; Po et al. 2011). The charcoal industry is a source of earning extra income for a large number of farmers and rural workers who reside in these centers, and, for some individuals, it is the primary source of income they depend on to support their families. The rudimentary process of charcoal production entails carbonization of wood with consequent release of smoke from kiln set ups that charcoal workers are continuously exposed to (Souza et al. 2005).

Charcoal production releases wood smoke that contains a wide variety of pollutants such as PM, PAH, CO, NOx, SOx, volatile organic compounds (VOCs) etc. Particulates can serve as vehicles for the transport of microorganisms such as viruses and bacteria to the lungs and blood stream. These pollutants affect public health as they can contribute to the development of cancer, heart and lung disease and reduce the body's ability to transport oxygen in the case of CO exposure (Ghosh et al. 1996; Anon 2011). Oxides of nitrogen and sulphur cause lung irritation leading to inflammation of the air passage thereby triggering airway obstruction and other more severe effects (Dost 1991). Pyrolysis, being a critical phase in charcoal production is usually monitored closely by someone who is responsible for the outcome of the process. The activity exposes the person to large amount of inhalable smoke for a period of 3-5 days (Souza et al. 2005). Crystalline silica, one of the major components of particulate matter, has also been classified as a known human carcinogen and is associated with systemic autoimmune disease (IARC 1997).

In a study conducted in Greece among charcoal workers by Tzanakis et al. (2001), it was reported that cough, expectoration, wheezing and dyspnea were significantly more prevalent among charcoal workers when compared to individuals who were not exposed to smoke. The increase in the prevalence of respiratory disorders may be due to genetic mutation which can be triggered by environmental factors, thereby leading to allergic symptoms (Ediagbonya and Tobin 2013). Patients with pre-existing respiratory or heartrelated issues are usually at risk of contracting the most severe adverse health effects 
caused by exposure to inhalable particles (Schwartz and Dockery 1992; Sunyer et al. 1993).

Chronic exposure to particulate matter during childhood or adolescence can greatly reduce lung function (Gauderman 2004). Even acute exposure to wood smoke has been associated with increased risk of respiratory symptoms (Svedahl et al. 2009; Orozco-Levi et al. 2006). Obligatory continuous consumption, which is a unique property of air is demystified in that an average adult only requires about $1.4 \mathrm{~kg}$ of food, $2 \mathrm{~kg}$ of water while he requires about $14 \mathrm{~kg}$ of air each day. This is the rationale for unending research on air pollution (Ediagbonya and Tobin 2013). Lung diseases are basically of two types; obstructive and restrictive (Abuzant et al. 2015). Asthma is an example of obstructive lung disease (Colledge et al. 2010) while idiopathic lung fibrosis is an example of restrictive lung disease (Raghu et al. 2011). The mechanism of action of the former is that it blocks airway insomuch that air movement is impeded while the mechanism of action of the latter is such that there exists insufficient lung expansion (Abuzant et al. 2015). However, some lung diseases exhibit both obstructive and restrictive attributes (Gardner et al. 2011).

Spirometer is widely used in assessing lung function. It measures the volume and flow rate of inspired and expired air. Lung function tests (LFTs) are used to distinguish obstructive and restrictive diseases and determine the degree of associated changes (Colledge et al. 2010; Holguin 2012). Forced Expiratory Volume in the first second $\left(\mathrm{FEV}_{1}\right)$ and Forced Vital Capacity (FVC) are two of the parameters measured by a spirometer (Quadrelli et al. 2007). The peak expiratory flow rate (PEFR) is the maximum flow achieved during an expiration delivered with maximal force starting from the level of maximum lung inflation. Value obtained may vary depending on the properties and preferences of the instrument used (Quanjer et al. 1997). PEFR is important in the routine assessment of healthy and asthmatic children (Seck 1991). FEV $\mathrm{FV}_{1}$ is the maximal volume of air exhaled in the first second of a forced expiration from a position of full inspiration (Miller et al. 2005; Abuzant et al. 2015). FVC is the maximal volume of air exhaled with maximally forced effort from a maximal inspiration. In other words, it is the vital capacity performed with a maximally forced expiratory effort, expressed in litres at body temperature and ambient pressure saturated with water vapour (Miller et al. 2005).

The most important health effects associated with exposure to $\mathrm{CO}$ are due to its strong bond with the hemoglobin molecule, forming carboxyhaemoglobin $(\mathrm{COHb})$. The $\mathrm{COHb}$ impairs the oxygen-carrying capacity of the blood, putting a strain on tissues with high oxygen demand, such as the heart and the brain. Carbon monoxide also binds to cytochrome oxidase, which could reduce the cells' ability to utilize oxygen (Ward 1999; WHO 1999; Varon et al. 1999). Studies on emission of pollutant gases and particles from charcoal production activities and associated health status of occupationally exposed charcoal workers in rural areas of Nigeria are scanty. Thus, this study aimed to assess (1) the impact of charcoal production on air quality from pyrolysis and charcoal removal activities and (2) to assess the human respiratory health status among the occupationally exposed workers. 


\section{Methods}

\section{Study areas}

This research is based on comparative cross-sectional study. It entails the use of questionnaires to obtain socio-demographic data, monitoring of gases $\left(\mathrm{CO}, \mathrm{CO}_{2}, \mathrm{NO}_{2}\right.$ and $\left.\mathrm{SO}_{2}\right)$ and particulate matter $\left(\mathrm{PM}_{2.5}\right)$ with subsequent determination of how the lung functions and carboxyheamoglobin among occupationally exposed charcoal workers and non-charcoal workers. The study was conducted at Igbo-Ora and Alabata settlements in Oyo and Ogun States respectively.

\section{Study population}

The participants selected for this study were charcoal workers and non-charcoal workers in Igbo-Ora and Alabata. Socio-demographic characteristics such as age, gender, educational status, marital status, religion and tribe were obtained from the participants.

\section{Inclusion criteria for charcoal workers}

Must be engaged in charcoal production within any of the selected settlements.

Must have been involved in charcoal production at least 1 month before the data were collected.

\section{Inclusion criteria for non-charcoal production workers}

Must not be engaged in charcoal production within any of the selected settlements.

Must not be involved in charcoal production but live within the selected settlements.

\section{Sampling procedure}

Purposive sampling technique was used to select the communities for this study Alabata in Ogun State and Igbo-ora in Oyo State. These communities were two of the major hubs of charcoal production in South Western Nigeria. Estimated sample size of 298 charcoal workers of the settlements in Alabata and Igbo-Ora were selected systematically while 298 non-charcoal workers were selected based on the inclusion criteria for non-charcoal workers. The sample size for the study was 298 respondents per group (i.e. 298 subjects and 298 controls). Alabata and Igbo-ora, had 149 subjects and 149 respectively. However, the selected communities differ in the number of charcoal workers, hence, proportional allocation was applied. A list containing the names of all charcoal workers in the selected communities was obtained from the secretary of their union and simple arithmetic was used to determine the number of charcoal workers to be selected in each community.

$$
\text { P.A. }=\frac{\text { Number of charcoal workers in each community }}{\text { Total number of charcoal workers in selected communities }} \times \text { Sample size }
$$

where P.A. = Proportional allocation.

Proportional allocation gives the number of participants to be selected from the list of charcoal workers in each community. The participants for this study were then selected using systematic random sampling where the required numbers of charcoal workers derived from proportional allocation were selected using a sampling interval $K$. The interval $K$ was calculated by dividing the number of charcoal workers on the list by value 
derived from proportional allocation. The sampling was done by selecting a name on list randomly and then every $K$ th name was selected until the required numbers of subjects were selected. Hence, the list containing names of charcoal workers in each community served as the sampling frame. The survey was carried out from May to July, 2015. The survey instrument was initially designed in English, translated to local languages, and then translated back to English by a translator to ensure that the translated version captured the questions correctly. The interviews were conducted in Yoruba, Tiv, Igbo and Hausa which were the primary languages of the interviewees. In order to ensure accuracy and validity, the field data collected were recorded on the field data sheets and were double-entered. A semi-structured interviewer administered questionnaire was used to obtain information on the common health hazards of participants associated with charcoal production and non-charcoal workers as controls.

\section{Data collection for gases and human exposure assessment}

Monitors were placed within $1 \mathrm{~m}$ radius of the kiln. The $1 \mathrm{~m}$ was used because charcoal workers keep an average distance of $1 \mathrm{~m}$ to the kilns (smoke sources) during charcoal production. The aim of the monitoring was to assess the concentration of pollutant gases and particles viz-a-viz exposure by charcoal workers. The charcoal production activities monitored for this study were pyrolysis and removal. Carbon monoxide was monitored using Extech $\mathrm{CO} 10 \mathrm{~m} .4 \mathrm{~h}$ monitoring of $\mathrm{CO}$ was carried out during pyrolysis with measurements taken at $5 \mathrm{~min}$ intervals. The $\mathrm{CO}$ meter was calibrated before use and during period of monitoring by zeroing at regular intervals. Carbon dioxide was monitored using Telaire 7001 carbon dioxide and temperature monitor. $4 \mathrm{~h}$ monitoring of $\mathrm{CO}_{2}$ was carried out during pyrolysis with measurements taken at 5 min intervals. The $\mathrm{CO}_{2} \mathrm{~m}$ was calibrated before use and during period of monitoring by zeroing at regular intervals. Sulphur dioxide was monitored using Z-1300 Sulfur dioxide meter during pyrolysis for $4 \mathrm{~h}$. The measurements were taken at $5 \mathrm{~min}$ intervals. The $\mathrm{SO}_{2} \mathrm{~m}$ was calibrated before use and during period of monitoring by zeroing at regular intervals. Nitrogen dioxide $\left(\mathrm{NO}_{2}\right)$ was monitored during pyrolysis for $4 \mathrm{~h}$ using Z-1400 Nitrogen dioxide meter and readings were recorded at $5 \mathrm{~min}$ interval. The $\mathrm{NO}_{2} \mathrm{~m}$ was calibrated before use and during period of monitoring by zeroing at regular intervals according to the manuals. Particulate matter was monitored using MIE pDR-1500 Active Personal Particulate Monitor. Monitoring of particulate matter $\left(\mathrm{PM}_{2.5}\right)$ was carried out during the pyrolysis and removal processes. The measurements were taken are real time. The equipment were placed about one (1) $\mathrm{m}$ from the production stand. However, monitoring during charcoal removal processes varied between 2 and $4 \mathrm{~h}$ depending on the size of the earth kiln and the number of people involved. During the removal process, monitoring of $\mathrm{CO}, \mathrm{CO}_{2}, \mathrm{SO}_{2}$ and $\mathrm{NO}_{2}$, were also done and measurements were taken at $5 \mathrm{~min}$ intervals.

Spirometry examination was performed using a calibrated Piko-1 spirometer to assess forced expiratory volume in the first second of expiration $\left(\mathrm{FEV}_{1}\right)$ and peak expiratory flow rate (PEFR) in order to determine the lung function of respondents. Each subject was made to complete a dynamic spirometry with at least three acceptable and two reproducible maneuvers according to standard guidelines. Expected values for $\mathrm{FEV}_{1}$ and PEFR were derived via equations reported by Ingle et al. (2005) using age and height of 
respondents. Non-invasive pulse $\mathrm{CO}$-oximeter ( $\operatorname{Rad}-57)$ was used to assess the $\mathrm{COHb}$ level of research participants. Weighing balance and meter rule were used to take anthropometric measurements of charcoal workers and non-charcoal workers in the study areas from which body mass index (BMI) was calculated.

\section{Air quality index (AQI)}

Air quality index (AQI) is a standardized method for assessing the quality of air using five criteria pollutants (ground level ozone, $\mathrm{SO}_{2}, \mathrm{NO}_{2}, \mathrm{CO}$ and $\left.\mathrm{PM}\right)$. Four of them $\left(\mathrm{SO}_{2}\right.$, $\mathrm{NO}_{2}, \mathrm{CO}$ and $\mathrm{PM}_{2.5}$ ) were monitored in this study.

$\mathrm{AQI}$ was calculated using the formula below:

$$
I_{p}=\frac{I_{H I}-I_{L O}}{B P_{H I}-B P_{L O}}\left(C_{P}-B P_{L O}\right)+I_{L O}
$$

$\mathrm{Cp}=$ the rounded concentration of pollutant $\mathrm{p}$; Ip: the index for pollutant $\mathrm{p} ; \mathrm{I}_{\mathrm{HI}}$ : the $\mathrm{AQI}$ value corresponding to $\mathrm{BP}_{\mathrm{HI}} ; \mathrm{I}_{\mathrm{LO}}$ : the $\mathrm{AQI}$ value corresponding to $\mathrm{BP}_{\mathrm{LO}} ; \mathrm{BP}_{\mathrm{HI}}=$ the breakpoint that is greater than or equal to $\mathrm{Cp} ; \mathrm{BP}_{\mathrm{LO}}=$ the breakpoint that is less than or equal to Cp (USEPA 2006).

\section{Data analysis}

Data was entered and analysed using statistical package for the social sciences (SPSS) version 20. Descriptive and inferential statistics were used in this study. Descriptive statistics was used to summarize data. Mean \pm standard deviation (SD) and range was calculated for the emissions $\left(\mathrm{CO}, \mathrm{CO}_{2}, \mathrm{SO}_{2}, \mathrm{NO}_{2}\right.$ and $\left.\mathrm{PM}_{2.5}\right)$ and biomarkers $\left(\mathrm{FEV}_{1}\right.$, PEFR $\mathrm{COHb}$ and $\mathrm{BMI}$ ) of respondents. $T$ test was used to test for any significant differences in $\mathrm{FEV}_{1}$, PEFR, COHb and BMI between respondent groups (subject and controls). $T$ test was also used to compare actual and expected values of FEV ${ }_{1}$ and PEFR. Simple linear regression was used to determine the relationship between two quantitative variables. Pearson correlation test was carried out to check for relationships between quantitative variables. Smoking status of respondents was determined before recruitment for the study. Only non-smokers were selected to reduce the number of potential confounding variables. Multiple linear regression was used to statistically test for the confounding effect of the use of biomass fuel for household cooking. Use of biomass fuel was not a statistically significant predictor of the carboxyheamoglobin $(\mathrm{COHb})$ and lung function (PEFR and FEV1).

\section{Results}

\section{Socio-demographic characteristics of respondents}

Table 1 shows the socio-demographic characteristics of respondents. Majority of charcoal workers were within age 21-30 years (43.9\%), males (73.7 \%), married (73.7 \%), Christians $(86.0 \%)$, Tiv (64.9 \%) with no education (35.1\%). The mean age of charcoal workers was $32.67 \pm 10.47$. Majority of non-charcoal workers were within age 31-40 years (38.6 \%), males (71.9\%), married (56.1\%), Christians (63.2\%), Yoruba (66.7 \%) with tertiary education (36.8\%). The mean age of non-charcoal workers was $35.46 \pm 12.82$ (Fig. 1) 
Table 1 Socio-demographic characteristics of respondents

\begin{tabular}{lllc}
\hline Socio-demographic characteristics & Subgroups & \multicolumn{2}{c}{ Percentage } \\
\cline { 3 - 4 } & & Subjects & Controls \\
\hline Mean age of subjects & $\leq 20$ & 10.5 & 7.0 \\
$32.67 \pm 10.47$ & $21-30$ & 43.9 & 35.1 \\
Mean age of controls & $31-40$ & 31.6 & 38.6 \\
$35.46 \pm 12.82$ & $41-50$ & 7.0 & 5.3 \\
& $>50$ & 7.0 & 14.0 \\
Gender & Male & 73.7 & 71.9 \\
& Female & 26.3 & 28.1 \\
Educational status & No education & 35.1 & 17.5 \\
& Primary education & 31.6 & 21.1 \\
& Secondary education & 31.5 & 24.6 \\
Marital status & Tertiary education & 1.8 & 36.8 \\
& Married & 73.7 & 56.1 \\
Religion & Single & 26.3 & 43.9 \\
& Christianity & 86.0 & 63.2 \\
Tribe & Islam & 14.0 & 36.8 \\
& Yoruba & 12.3 & 66.7 \\
& Tiv & 64.9 & 21.1 \\
& Hausa & - & 12.2 \\
\hline & Others & 22.8 & - \\
\hline
\end{tabular}

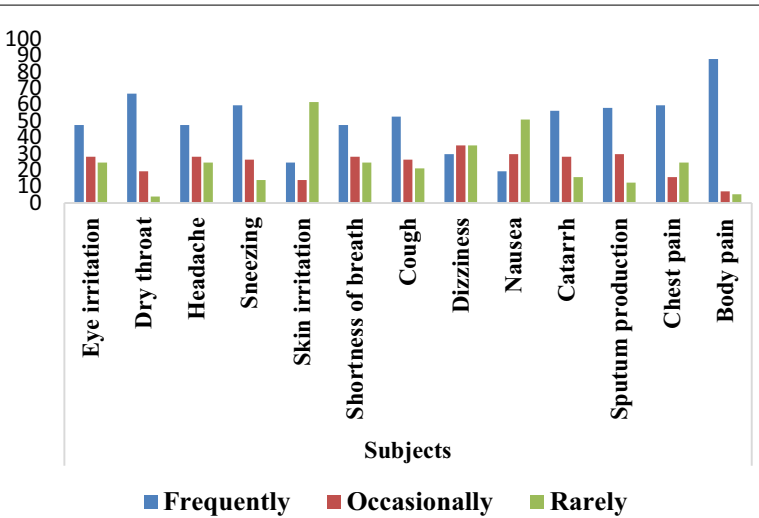

Fig. 1 Perception of charcoal workers to common symptoms and conditions

\section{Perception of respondents to common symptoms and conditions}

Figures 2 and 3 showed the perception of charcoal workers and non-charcoal workers to common symptoms and conditions. Majority of charcoal workers experienced eye irritation (47.4\%), dry throat (66.7\%), headache (47.4\%), sneezing (59.6\%), shortness of breath (47.4\%), cough (52.6\%), catarrh (56.1\%), sputum production (57.9\%), chest pain $(59.6 \%)$ and frequent body pain $(87.7 \%)$ whereas majority of non-charcoal workers experienced eye irritation (68.4\%), dry throat (66.7\%), headache (52.6\%), sneezing (52.6\%), skin irritation (77.2\%), shortness of breath $(80.7 \%)$, cough $(75.4 \%)$, dizziness $(70.2 \%)$, nausea $(89.4 \%)$, catarrh $(54.4 \%)$, sputum production $(64.9 \%)$, chest pain (75.4\%) and occasional body pain (50.9\%). 


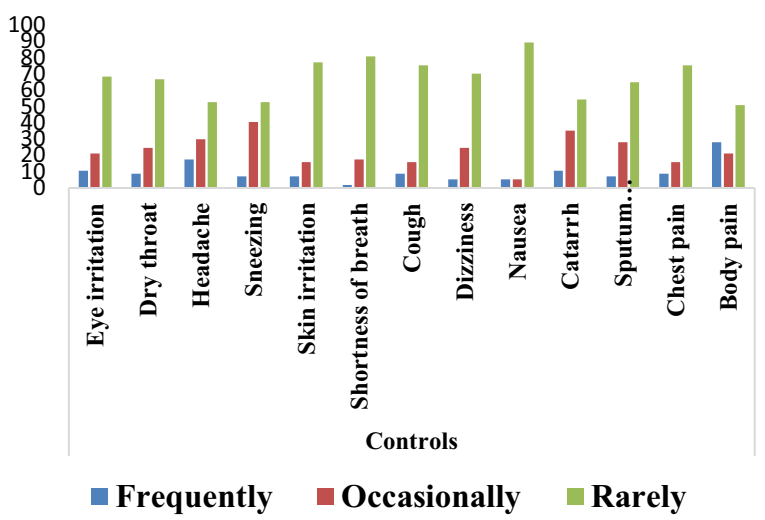

Fig. 2 Perception of non-charcoal workers to common symptoms and conditions

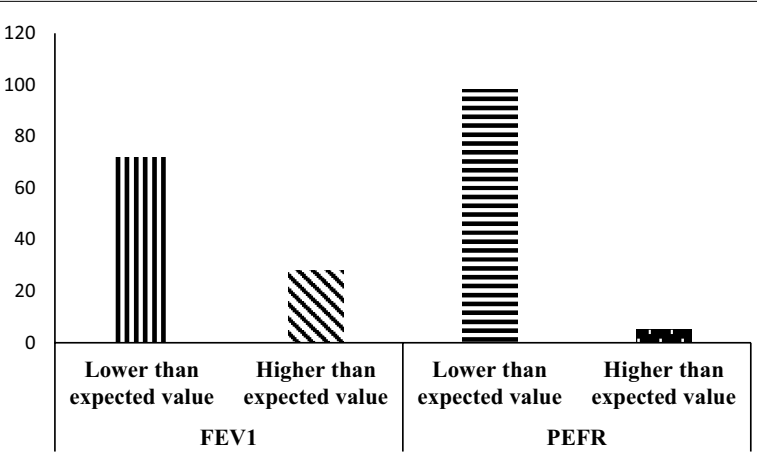

Fig. 3 Proportion of charcoal workers with FEV1 and PEFR values lower or higher than expected values

\section{Emissions from pyrolysis, removal processes and air quality index}

The mean concentration of the gases and $\mathrm{PM}_{2.5}$ monitored at the study areas are presented in Tables 2 and 3. At Alabata settlements during the pyrolysis process, $\mathrm{NO}_{2}$ varied from $0.19 \pm 0.22 \mathrm{ppm}$ (Ikugba) to $0.48 \pm 0.71 \mathrm{ppm}$ (Ayogun); $\mathrm{SO}_{2}$ varied from $1.74 \pm 2.19 \mathrm{ppm}$ (Raka) to $2.93 \pm 3.21 \mathrm{ppm}$ (Ayogun); CO ranged from $2.93 \pm 3.21 \mathrm{ppm}$ (Ayogun) to $585 \pm 163 \mathrm{ppm}$ (Ikugba); $\mathrm{CO}_{2}$ varied from $317 \pm 147 \mathrm{ppm}$ (Raka) to

Table 2 Range and mean \pm SD of pyrolysis and charcoal harvesting at settlements in Alabata, Ogun State

\begin{tabular}{|c|c|c|c|c|c|c|c|}
\hline & \multicolumn{4}{|l|}{ Alabata (pyrolysis) } & \multicolumn{3}{|c|}{ Alabata (harvesting) } \\
\hline & Oluwotiti & Raka & lkugba & Ayogun & Adaako & Raka & Fojubaye \\
\hline $\begin{array}{l}\mathrm{NO}_{2}(\mathrm{ppm}) \\
\quad \text { mean } \pm \mathrm{SD}\end{array}$ & $0.25 \pm 0.47$ & $0.20 \pm 0.27$ & $0.19 \pm 0.22$ & $0.48 \pm 0.71$ & $0.018 \pm 0.025$ & $0.031 \pm 0.058$ & $0.08 \pm 1.35$ \\
\hline $\begin{array}{l}\mathrm{SO}_{2}(\mathrm{ppm}) \\
\quad \text { mean } \pm \mathrm{SD}\end{array}$ & $1.89 \pm 2.77$ & $1.74 \pm 2.19$ & $2.85 \pm 1.83$ & $2.93 \pm 3.21$ & $0.0075 \pm 0.011$ & $0.012 \pm 0.016$ & $0.02 \pm 0.05$ \\
\hline $\begin{array}{l}\mathrm{CO}(\mathrm{ppm}) \\
\quad \text { mean } \pm \mathrm{SD}\end{array}$ & $280 \pm 149$ & $96.8 \pm 57.1$ & $585 \pm 163$ & $2.93 \pm 3.21$ & $1.50 \pm 2.05$ & $14.65 \pm 5.31$ & $13.4 \pm 6.46$ \\
\hline $\begin{array}{l}\mathrm{CO}_{2}(\mathrm{ppm}) \\
\quad \text { mean } \pm \mathrm{SD}\end{array}$ & $1986 \pm 1648$ & $964 \pm 819$ & $3877 \pm 2608$ & $3021 \pm 1958$ & $221 \pm 27$ & $317 \pm 147$ & $714 \pm 673$ \\
\hline $\begin{array}{r}\mathrm{PM}_{2.5}\left(\mu \mathrm{g} / \mathrm{m}^{3}\right) \\
\text { mean } \pm \mathrm{SD}\end{array}$ & $17,000 \pm 270,000$ & $6550 \pm 7520$ & $34,000 \pm 17,000$ & $18,000 \pm 9000$ & $430 \pm 110$ & $279 \pm 230$ & $103 \pm 191$ \\
\hline
\end{tabular}




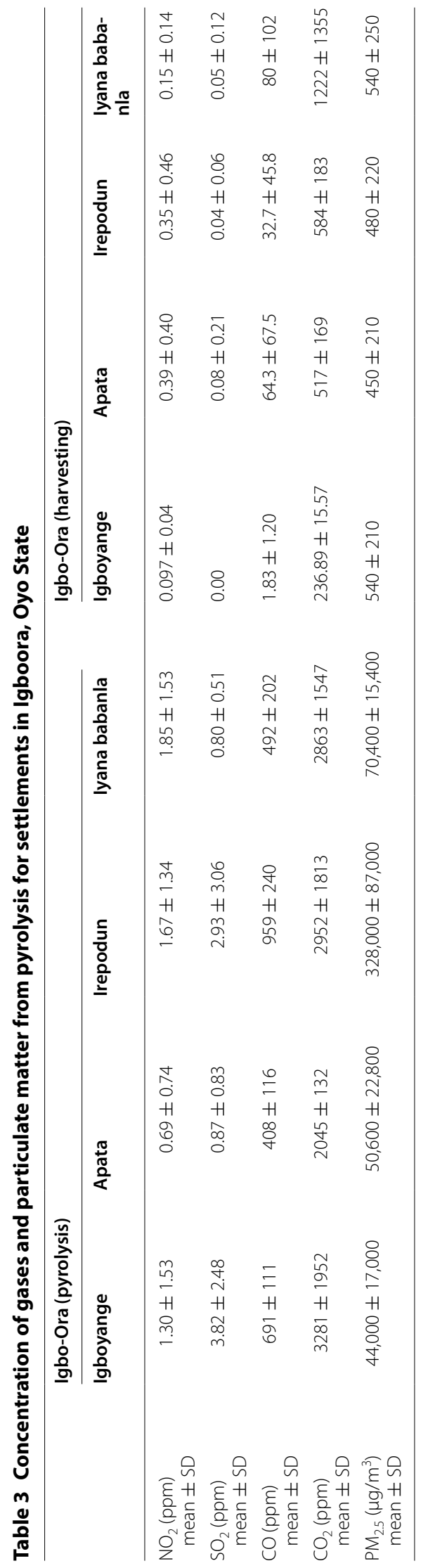


$3877 \pm 2608 \mathrm{ppm}$ (Ikugba) while $\mathrm{PM}_{2.5}$ varied from $103 \pm 191 \mu \mathrm{gm}^{-3}$ (Fojubaye) to $34,000 \pm 17,000 \mathrm{\mu gm}^{-3}$ (Ikugba). At Igbo-Ora settlements, $\mathrm{NO}_{2}$ varied from $0.69 \pm 0.74$ (Apata) to $1.85 \pm 1.53 \mathrm{ppm}$ (Iyana babanla); $\mathrm{SO}_{2}$ varied from $0.8 \pm 0.51 \mathrm{ppm}$ (Iyana babanla) to $3.82 \pm 2.48 \mathrm{ppm}$ (Igboyange); $\mathrm{CO}$ ranged from $408 \pm 116 \mathrm{ppm}$ (Apata) to $959 \pm 240 \mathrm{ppm}$ (Irepodun); $\mathrm{CO}_{2}$ varied from $2045 \pm 132 \mathrm{ppm}$ (Apata) to $3281 \pm 1952 \mathrm{ppm}$ (Igboyange) and $\mathrm{PM}_{2.5}$ varied from 44,000 $\pm 17,000 \mu \mathrm{gm}^{-3}$ (Igboyange) to $328,000 \pm 87,000{\mu \mathrm{gm}^{-3}}^{-3}$ (Irepodun). Similar trend was obtained for the gases and $\mathrm{PM}_{2.5}$ monitored during the removal process at all the sites. Additionally, it is worthy to note that the concentration of all the gases and $\mathrm{PM}_{2.5}$ monitored were significantly $(\mathrm{p}<0.05)$ higher at Igbo-Ora compared to Alabata. This thus, shows that there are more charcoal production activities in Igbo-Ora area than in Alabata area. The air quality indexes of the settlements are presented in Table 4. All the settlements investigated recorded poor air quality indexes except the Adaako area that recorded good air quality index for $\mathrm{CO}$ and $\mathrm{SO}_{2}$ and Fojubaye with good air quality index for $\mathrm{SO}_{2}$.

\section{Biomarker assessment of respondents and relationships with emissions during charcoal production}

The mean and standard deviation (SD) of $\mathrm{FEV}_{1}$, PEFR, COHb and BMI among charcoal workers and non-charcoal workers are presented in Table 5. The FEV 1 for charcoal and non-charcoal workers were $2.35 \pm 0.73$ and $2.69 \pm 0.56$ respectively while the PEFR for charcoal workers and non-charcoal workers were $253.72 \pm 103.45$ and $330.02 \pm 94.61$ respectively $(\mathrm{p}<0.01)$. The $\mathrm{COHb}$ for charcoal workers and non-charcoal workers were $13.28 \pm 3.91$ and $8.50 \pm 3.68$ respectively $(\mathrm{p}<0.01)$ while the BMI for charcoal and noncharcoal workers were $21.97 \pm 2.19$ and $23.36 \pm 3.74$ respectively $(\mathrm{p}<0.05)$. The comparison between actual and expected mean values for $\mathrm{FEV}_{1}$ and PEFR among charcoal workers is presented in Table 6 . There was a statistically significant $(\mathrm{p}<0.01)$ difference between actual and expected values of $\mathrm{FEV}_{1}$ and PEFR among charcoal workers. Figure 3 shows the proportion of charcoal workers with $\mathrm{FEV}_{1}$ and PEFR values lower or higher than expected values. The results showed that majority of charcoal workers recorded $\mathrm{FEV}_{1}(71.9 \%)$ and PEFR (98.2 \%) values lower than the expected values.

Table 4 Air quality index of study sites

\begin{tabular}{|c|c|c|c|c|}
\hline Location & $\mathrm{AQI}\left(\mathrm{SO}_{2}\right)$ & $A Q I\left(\mathrm{NO}_{2}\right)$ & AQI (CO) & $\mathrm{PM}_{2.5}$ \\
\hline Oluwotiti, Alabata & Extremely hazardous & Not applicable & Extremely hazardous & Extremely hazardous \\
\hline Adaako, Alabata & 7.8 (good) & Not applicable & 12.4 (good) & 356.4 (hazardous) \\
\hline Raka, Alabata & Extremely hazardous & Not applicable & Extremely hazardous & Extremely hazardous \\
\hline Ikugba, Alabata & Extremely hazardous & Not applicable & Extremely hazardous & Extremely hazardous \\
\hline Ayogun, Alabata & Extremely hazardous & Not applicable & Extremely hazardous & Extremely hazardous \\
\hline Fojubaye, Alabata & 25 (good) & Not applicable & 166.2 (unhealthy) & 172.8 (unhealthy) \\
\hline Igboyange, Igboora & Extremely hazardous & Not applicable & Extremely hazardous & Extremely hazardous \\
\hline Apata, Igboora & 343.3 hazardous & Not applicable & Extremely hazardous & Extremely hazardous \\
\hline Irepodun, Igboora & Extremely hazardous & 331.5 (hazardous) & Extremely hazardous & Extremely hazardous \\
\hline Iyana Babanla, Igboora & 298.7 (very unhealthy) & 334.0 (hazardous) & Extremely hazardous & Extremely hazardous \\
\hline
\end{tabular}


Table 5 Comparison of biomarkers between respondent types

\begin{tabular}{llll}
\hline & Subject & Control & p-value \\
\hline FEV ${ }_{1}$ & & & \\
Range & $0.88-4.21$ & $1.49-4.02$ & 0.06 \\
Mean \pm SD & $2.35 \pm 0.73$ & $2.69 \pm 0.56$ & \\
PEFR & & & 0.000 \\
Range & $104.00-618.00$ & $156.00-650$ & \\
Mean \pm SD & $253.72 \pm 103.45$ & $330.02 \pm 94.61$ & 0.000 \\
COHb (\%) & & & \\
Range & $5.00-20.00$ & $1.00-18.00$ & \\
Mean \pm SD & $13.28 \pm 3.91$ & $8.50 \pm 3.68$ & 0.019 \\
BMI (kg/m $\left.{ }^{2}\right)$ & $16.22-26.03$ & $18.03-35.06$ & \\
Range & $21.97 \pm 2.19$ & $23.36 \pm 3.74$ & \\
Mean $\pm S D$ & & & \\
\hline
\end{tabular}

Table 6 Comparison of actual and expected values of FEV 1 and PEFR

\begin{tabular}{llll}
\hline & FEV1 (actual) & FEV1 (expected) & p value \\
\hline Subjects & $2.35 \pm 0.73$ & $2.82 \pm 0.40$ & 0.000 \\
\hline & PEFR (actual) & PEFR (expected) & \\
\hline Subjects & $253.72 \pm 103.45$ & $529.61 \pm 41.52$ & 0.000 \\
\hline
\end{tabular}

The relationships between emissions during pyrolysis and biomarkers assessed among charcoal workers are presented in Table 7. Nitrogen dioxide correlated positively with $\mathrm{COHb}(\mathrm{r}=0.074)$ and $\mathrm{FEV}_{1}(\mathrm{r}=0.036)$ while it correlated negatively with PEFR

Table 7 Correlation between the quantitative variables

\begin{tabular}{|c|c|c|c|c|c|c|c|c|c|}
\hline $\begin{array}{l}\text { Pearson } \\
\text { correlation } \\
\text { coefficient } \\
\text { Sig ( } 2 \text { tailed) }\end{array}$ & $\mathrm{NO}_{2}$ & $\mathrm{SO}_{2}$ & CO & $\mathrm{CO}_{2}$ & $\mathrm{PM}_{2.5}$ & $\mathrm{COHb}$ & FEV $_{1}$ & PEFR & $\begin{array}{l}\text { Body mass } \\
\text { index }\end{array}$ \\
\hline $\mathrm{NO}_{2}$ & 1 & & & & & & & & \\
\hline $\mathrm{SO}_{2}$ & $\begin{array}{l}0.181^{* *} \\
0.000\end{array}$ & 1 & & & & & & & \\
\hline $\mathrm{CO}$ & $\begin{array}{l}0.477^{* *} \\
0.000\end{array}$ & $\begin{array}{l}0.390^{* *} \\
0.000\end{array}$ & 1 & & & & & & \\
\hline $\mathrm{CO}_{2}$ & $\begin{array}{l}0.261^{* *} \\
0.000\end{array}$ & $\begin{array}{l}0.422^{* *} \\
0.000\end{array}$ & $\begin{array}{l}0.525^{* *} \\
0.000\end{array}$ & 1 & & & & & \\
\hline PM & $\begin{array}{l}0.441^{* *} \\
0.000\end{array}$ & $\begin{array}{l}0.212^{* *} \\
0.000\end{array}$ & $\begin{array}{l}0.717^{* *} \\
0.000\end{array}$ & $\begin{array}{l}0.261^{* *} \\
0.000\end{array}$ & 1 & & & & \\
\hline $\mathrm{COHb}$ & $\begin{array}{l}0.074 \\
0.586\end{array}$ & $\begin{array}{l}-0.169 \\
0.209\end{array}$ & $\begin{array}{l}0.104 \\
0.441\end{array}$ & $\begin{array}{l}0.038 \\
0.781\end{array}$ & $\begin{array}{l}0.320^{*} \\
0.015\end{array}$ & 1 & & & \\
\hline $\mathrm{FEV}_{1}$ & $\begin{array}{l}0.036 \\
0.789\end{array}$ & $\begin{array}{l}-0.144 \\
0.286\end{array}$ & $\begin{array}{l}-0.173 \\
0.199\end{array}$ & $\begin{array}{l}-0.005 \\
0.973\end{array}$ & $\begin{array}{l}-0.027 \\
0.843\end{array}$ & $\begin{array}{l}-0.075 \\
0.577\end{array}$ & 1 & & \\
\hline PEFR & $\begin{array}{l}-0.017 \\
0.902\end{array}$ & $\begin{array}{l}-0.140 \\
0.300\end{array}$ & $\begin{array}{l}-0.077 \\
0.571\end{array}$ & $\begin{array}{l}0.024 \\
0.859\end{array}$ & $\begin{array}{l}-0.082 \\
0.545\end{array}$ & $\begin{array}{l}-0.122 \\
0.367\end{array}$ & $\begin{array}{l}0.875^{* *} \\
0.000\end{array}$ & 1 & \\
\hline BMI & $\begin{array}{l}-0.071 \\
0.599\end{array}$ & $\begin{array}{l}0.061 \\
0.655\end{array}$ & $\begin{array}{l}-0.116 \\
0.392\end{array}$ & $\begin{array}{l}-0.010 \\
0.943\end{array}$ & $\begin{array}{l}-0.144 \\
0.284\end{array}$ & $\begin{array}{l}-0.038 \\
0.777\end{array}$ & $\begin{array}{l}0.328^{*} \\
0.013\end{array}$ & $\begin{array}{l}0.279^{*} \\
0.036\end{array}$ & 1 \\
\hline
\end{tabular}

* Correlation is significant at the 0.05 level (2-tailed); ${ }^{*}$ correlation is significant at the 0.01 level (2-tailed) 
$(\mathrm{r}=-0.017)$ and BMI $(\mathrm{r}=-0.071)$. Sulphur dioxide correlated negatively with $\mathrm{COHb}$ $(\mathrm{r}=-0.169), \mathrm{FEV}_{1}(\mathrm{r}=-0.144)$ and PEFR $(\mathrm{r}=-0.14)$ while it correlated positively with BMI $(r=0.061)$. The value of CO showed negative correlation with $\mathrm{FEV}_{1}(r=-0.173)$, PEFR ( $\mathrm{r}=-0.077)$ and BMI $(\mathrm{r}=-0.116)$ while it correlated positively with $\mathrm{COHb}$ $(\mathrm{r}=0.104)$. The strength of the linear relationship between the levels of $\mathrm{CO}$ and $\mathrm{COHb}$ $\left(\mathrm{R}^{2}=1.08 \%\right)$ is depicted in Fig. 4. The $\mathrm{CO}_{2}$ correlated positively with $\mathrm{COHb}(\mathrm{r}=0.038)$ and PEFR $(r=0.024)$ while it correlated negatively with $\mathrm{FEV}_{1}(\mathrm{r}=-0.005)$ and BMI $(r=-0.010)$. There existed a significant positive correlation between $\mathrm{PM}_{2.5}$ and $\mathrm{COHb}$ $(\mathrm{r}=0.320, \mathrm{p}<0.05)$, while $\mathrm{PM}_{2.5}$ correlated negatively with $\mathrm{FEV}_{1}(\mathrm{r}=-0.027)$, PEFR $(\mathrm{r}=-0.082)$ and BMI $(\mathrm{r}=-0.144)$. Furthermore, BMI correlated positively with $\mathrm{FEV}_{1}$ $(\mathrm{r}=0.328, \mathrm{p}<0.05)$ and PEFR $(\mathrm{r}=0.279, \mathrm{p}<0.05)$ while it correlated negatively with $\mathrm{COHb}(\mathrm{r}=-0.038)$. The strength of the linear relationship $\mathrm{PM}_{2.5}$ recorded with $\mathrm{FEV}_{1}$ $\left(R^{2}=0.06 \%\right)$ and PEFR $\left(R^{2}=0.67 \%\right)$ are shown in Fig. 4 .

\section{Discussion}

Majority of charcoal workers experienced most of the reported symptoms and conditions such as eye irritation, dry throat, headache, sneezing, shortness of breath, cough, catarrh, sputum production, chest pain and frequent body pain whereas non-charcoal workers rarely experienced these symptoms and conditions. This may be due to emissions arising from charcoal production and adverse working conditions these charcoal workers are exposed to during and after the phases of charcoal production. This assertion is supported by Souza et al. (2005) who stated that work environment has influence on human health. In a study (Ediagbonya and Tobin (2013) that assessed air pollution and respiratory morbidity among 400 respondents in Sapele, Nigeria, shows

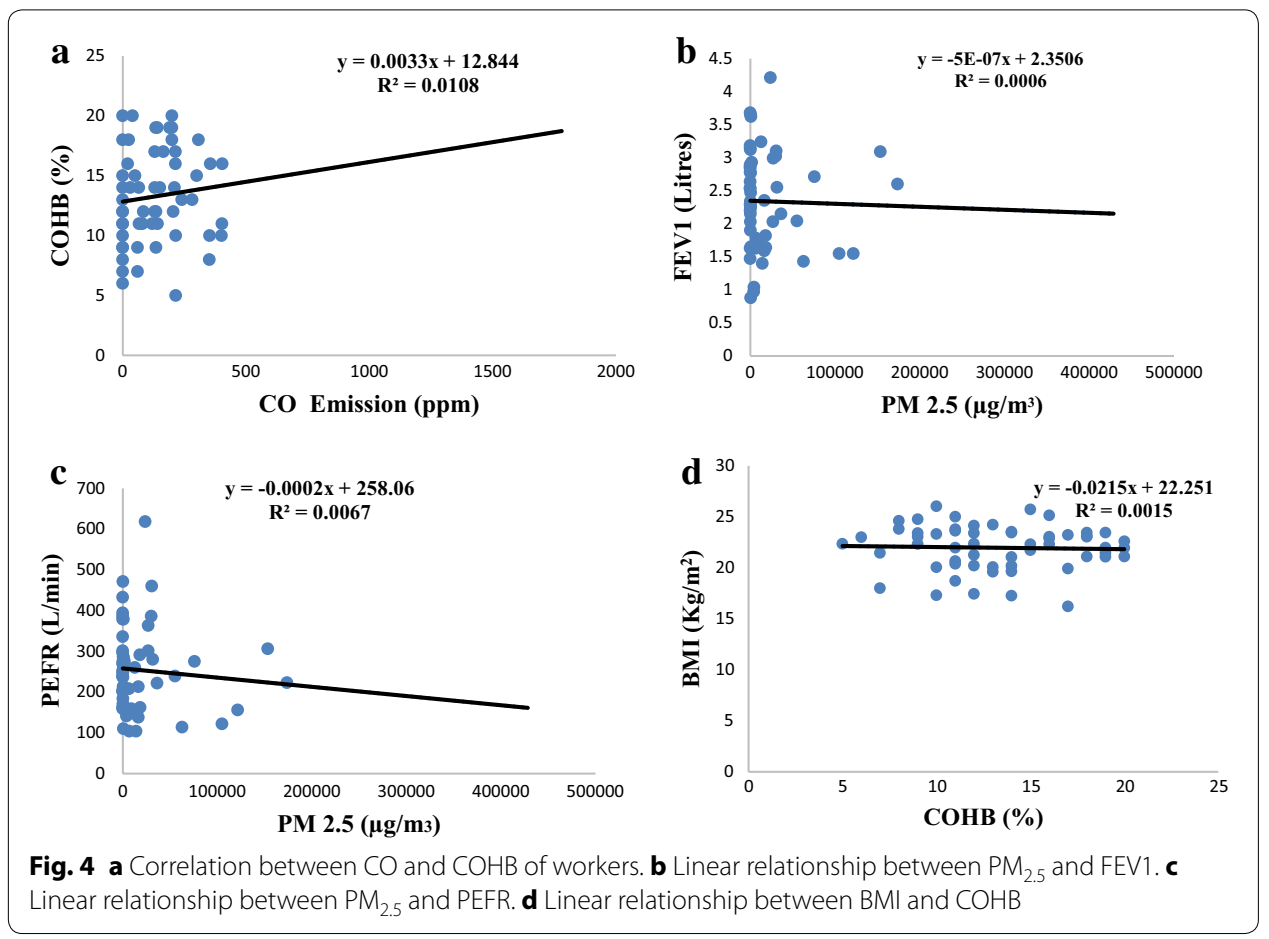


the prevalence of respiratory symptoms such as cough (10.5\%), phlegm (21.3\%), wheezing (13.5\%), difficulty in breathing (14.8\%), chest pain (13.8\%) and sore throat (10.3\%).

Cough alongside other symptoms such as sneezing, nasal secretion and sputum production have also been reported as common symptoms in previous studies by Tzanakis et al. (2001), Ibhazehiebo et al. (2007), Swiston et al. (2008), Souza et al. (2005), Keraka et al. (2013) and Adewole et al. (2013). As documented by Dost (1991), increase in cough and sputum expectoration could be explained by stating that aldehydes and acids reduce the ciliary activity of the respiratory tract, thereby interfering with the ability of the airway epithelium to clear mucus and remove particles and micro-organisms. In this study, eye irritation was one of the frequently experienced symptoms among charcoal workers and this may be due to causation of metabolite-induced opacification of the eye lenses by wood smoke which could result in cataract formation and eventually blindness (Rao 1995).

Although, no study to the best of our knowledge had reported gaseous emission from wood pyrolysis during charcoal production activities in Nigeria, previous studies have reported various anthropogenic emissions with varying concentrations of $\mathrm{CO}, \mathrm{CO}_{2}$, $\mathrm{NO}_{2}, \mathrm{SO}_{2}$ and particulate matter. For example, Akande et al. (2013) reported 20.09 ppm; 0.004 and $0.002 \mathrm{ppm}$ for $\mathrm{CO}_{2}, \mathrm{CO}$ and $\mathrm{SO}_{2}$ respectively at marine clay processing plant. Also, Adoki (2012) reported concentration range of $92-430 \mu \mathrm{gm}^{-3}(0.035-0.16 \mathrm{ppm})$ for $\mathrm{SO}_{2}$, and 81.0-150 $\mathrm{\mu gm}^{-3}(0.043-0.080 \mathrm{ppm})$ for $\mathrm{NO}_{2}$ in Niger/Delta. Recently, the National Environmental Standards and Regulatory Enforcement Agency in a study conducted in Abuja reported $0.375 \mathrm{ppm} ; 0.165 \mathrm{ppm} ; 0.260$ and $0.345 \mathrm{ppm}$ for $\mathrm{SO}_{2}, \mathrm{NO}_{2}$, $\mathrm{NO}$ and $\mathrm{NO}_{\mathrm{x}}$. The mean concentration of $\mathrm{SO}_{2}$ for the two study locations (Tables 2 and 3) clearly indicated that pyrolysis is a factor in air pollution compared to the removal of charcoal process. The general mean concentration of $\mathrm{SO}_{2}$ is above the $0.5 \mathrm{ppm}$ USEPA 3-h permissible limit. However, the reported ranges for charcoal removal process is within the $500{\mu \mathrm{gm}^{-3}}^{-3}(0.19 \mathrm{ppm})$ WHO $10 \mathrm{~min}$ exposure average (WHO 2006). Similarly, $\mathrm{NO}_{2}$ concentration reported for all the pyrolysis sites were above the WHO 1-h average time standard of $0.11 \mathrm{ppm}$.

As presented in Tables 2 and 3, the CO concentration during pyrolysis and harvesting ranged from $2.93 \pm 3.21 \mathrm{ppm}$ (Ayogun, Alabata) to $959 \pm 240 \mathrm{ppm}$ (Irepodun, IgboOra) and $1.5 \pm 2.05 \mathrm{ppm}$ (Adaako, Alabata) to $80 \pm 102 \mathrm{ppm}$ (Iyana Babanla. Igbo-Ora). These results indicate that the average CO concentration is above the Nigeria Ambient Air Quality Standard (NAAQS) which stipulates an average concentration of 10-20 ppm for an 8-hourly average time (FEPA 1999). However, except for Apata, Irepodun and Iyana Babanla areas, charcoal removal releases low levels of $\mathrm{CO}$ into the atmosphere. The concentration of $\mathrm{CO}_{2}$ varied from $964 \pm 819 \mathrm{ppm}$ (Raka, Alabata) to $3877 \pm 2668 \mathrm{ppm}$ (Ikugba, Alabata) and from $221 \pm 27 \mathrm{ppm}$ (Adaako, Alabata) to $1222 \pm 1355 \mathrm{ppm}$ (Iyana Babanla, Igbo-Ora) for pyrolysis and removal processes respectively. The concentration for all the settlements was above the $600 \mathrm{ppm}$ maximum natural concentration standard and the recommended WHO threshold limit value of $500 \mathrm{ppm}$ that is safe for adult for an 8-hourly work day.

In addition, $\mathrm{PM}_{2.5}$ concentration was generally above the WHO guideline of $25 \mathrm{\mu gm}^{-3}$ for $24 \mathrm{~h}$ mean period. The observed concentration of $\mathrm{PM}_{2.5}$ is a pointer towards health effects for the occupationally exposed workers many of which do not make use of 
personal protective equipment. Also, particulate matter can easily react with polycyclic aromatic hydrocarbons to form photochemical smog in the presence of ultraviolent light. Except for $\mathrm{SO}_{2}$ in Adaako and Fojubaye and $\mathrm{CO}$ in Adaako, the air quality indexes ranged from unhealthy to extremely hazardous (Table 4).

There was a statistically significant $(\mathrm{p}<0.01)$ difference in PEFR between charcoal and non-charcoal workers. This shows that the reduction in PEFR values among charcoal workers is very evident. Exposure to smoke has implications for significant reduction in mean PEFR values for charcoal workers $(253.72 \pm 103.45)$ who were exposed to smoke from kilns used for charcoal production as compared to mean PEFR value for non-charcoal workers $(330.02 \pm 94.61)$. This result confirms the studies by Ediagbonya and Tobin (2013) and Ibhazehiebo et al. (2007) that reported reduced PEFR values among subjects exposed to smoke as compared to controls. Several other studies have also reported reduction in PEFR values and increased respiratory symptoms (Alakija et al. 1990; Ellegard 1994; Tzanakis et al. 2001). There was reduction in $\mathrm{FEV}_{1}$ of charcoal workers compared to non-charcoal workers which was not significantly. In a study that investigated respiratory symptoms in charcoal production workers in Brazil by Souza et al. (2005) reported that mean $\mathrm{FEV}_{1}$ of 65 charcoal production workers was $3.24 \pm 0.82$ $\mathrm{L}\left(93.2 \pm 16.0 \%\right.$ of predicted). The $\mathrm{FEV}_{1}$ value is higher than that recorded in this study $(2.35 \pm 0.73)$. Also, a study conducted in Palestine among workers in charcoal factories, reported that more subjects recorded decreased $\mathrm{FEV}_{1}$ values than members of the control group ( $\mathrm{p}=0.015)$ Abuzant et al. (2015).

Furthermore, $\mathrm{PM}_{2.5}$ correlated negatively with $\mathrm{FEV}_{1}(\mathrm{r}=-0.027)$ and PEFR $(\mathrm{r}=-0.082)$. This result is consistent with the mechanism of action of inhalable particulate matter as lung function decreases with increase in levels of particulate matter especially those with sizes less than 10 microns. The result also showed that there was a statistically significant $(\mathrm{p}<0.01)$ difference in the actual and expected values of $F E V_{1}$ and PEFR among charcoal workers where 71.9 and $98.2 \%$ of charcoal workers recorded $\mathrm{FEV}_{1}$ and PEFR values lower than the expected values respectively. This is an indication that charcoal production has a measurable effect on the respiratory health of charcoal workers due to exposure of charcoal workers to high levels of $\mathrm{PM}_{2.5}$, thereby reducing lung function assessed through $\mathrm{FEV}_{1}$ and PEFR. In addition, components of wood smoke such as $\mathrm{SO}_{2}, \mathrm{NO}_{2}$ and particulate matter have been reported to have adverse effect on the lung function and increase respiratory symptoms even in low concentrations (Gong 1992). The effect of charcoal dusts on lung function can be explained in terms of occupational exposures to particles in which the entrance of dust particles trigger inflammatory reactions, leading to lung fibrosis with attendant reduction in $\mathrm{FVC}$ and $\mathrm{FEV}_{1}$ values (Longo et al. 2011).

The result of $\mathrm{COHb}$ presented in Table 5 showed the range of $\mathrm{COHb}$ in charcoal workers is $5-20 \%$ with mean concentration of $13.28 \pm 3.91 \%$ while it ranged from 1.00 to $18.00 \%$ with mean concentration of $8.50 \pm 3.68 \%$ among controls. Generally, the mean concentration recorded in subjects and controls exceeded the acceptable limit of $2.5 \%$ (WHO 1999). The COHb level of 3-8 \% has been reported in regular workers and higher concentration in heavy smokers and drivers working in high traffic density areas (Sen et al. 2010). The result of the study confirms the reported ranges of $\mathrm{COHb}$ for subjects and controls. In acute and chronic $\mathrm{CO}$ toxicity, the common symptoms includes fatigue, 
signs of upper respiratory tract infections, dyspnea, chest pain, palpitations, lethargy, confusion, depression, hallucinations, agitation, vomiting, diarrhea, abdominal pain, headache, dizziness, blurred vision, syncope, seizure, urinary incontinence, memory and gait disturbance, neurological disorders, cognitive functions impairment and gradually developing psychiatric symptoms (Van Meter 2010; Nelson and Hoffman 2010; Shochat and Luchessi 2013). Death from acute CO poisoning is not uncommon in developed countries most especially in fire related poisoning (Van Meter 2010). However, several cases of acute death arising from acute $\mathrm{CO}$ poisoning have been reported in Nigeria due to exposure to generators.

Levels of $\mathrm{COHb}$ in charcoal workers were significantly $(\mathrm{p}<0.01)$ higher than the non-charcoal workers and WHO guideline of $2.5 \%$ (WHO 1999). The mean \% $\mathrm{COHb}$ among charcoal workers was fivefold higher than the WHO guideline. This indicates that charcoal workers are exposed high levels of $\mathrm{CO}$ during charcoal production. This further explains the fact that there was a positive correlation between $\mathrm{CO}$ and $\mathrm{COHb}$ $\left(\mathrm{r}=0.104, \mathrm{R}^{2}=1.08 \%\right)$. This is also consistent as COHb levels rise in charcoal workers with increase in $\mathrm{CO}$ emission from kiln set ups. High levels of $\mathrm{CO}$ resulting in $\mathrm{COHb}$ level between 5 and $9 \%$ has been reported in persons exposed to wood smoke (Ellegard 1994). Hoek et al. (2002) reported that average BMI was lower for those exposed to traffic-related air pollutants and higher BMI for those with air pollutants exposure. Significant difference was recorded for BMI between those living near a road and those that do not live near a major road. Similarly, McConnell et al. (2014) reported that exposure to secondhand smoke (SHS), maternal smoking during pregnancy and vehicular air pollution have associations with BMI. Though the mean BMI of charcoal workers and noncharcoal workers fall within normal or healthy weight (NOO 2009), charcoal workers recorded a significantly $(\mathrm{p}<0.05)$ lower BMI than non-charcoal workers. This indicates that charcoal workers have less body mass when compared to non-charcoal workers. The mean BMI reported by Souza et al. (2005) $\left(25.7 \pm 3.85 \mathrm{~kg} / \mathrm{m}^{2}\right)$ is also higher than that recorded in this study $(21.97 \pm 2.19)$ for charcoal workers.

\section{Conclusion and recommendations}

This study assessed biomarkers such as $\mathrm{FEV}_{1}$, PEFR, COHb and BMI and their relationships with emissions from charcoal production among charcoal workers and non-charcoal workers in Igbo-Ora in Oyo State and Alabata in Ogun State, Nigeria. Majority of charcoal workers experienced frequently most of the symptoms and conditions while non-charcoal workers rarely experienced symptoms. Lung function test carried out on respondents revealed that there was reduction in PEFR and $\mathrm{FEV}_{1}$ values among charcoal workers when compared to non-charcoal workers. Levels of $\mathrm{COHb}$ among charcoal workers was also significantly higher than that of non-charcoal workers. The mean BMI among charcoal workers was lower than the record for non-charcoal workers. The study also revealed significant relationships between emissions from charcoal production and biomarkers of charcoal workers. This study suggest that charcoal workers should be enlightened on the adverse health effects of emissions arising from charcoal production and trained on ways to reduce their exposures to these emissions. A routine respiratory and carboxyhaemoglobin assessment of persons involved in charcoal production is also recommended. 


\section{Authors' contributions}

$\mathrm{OOO}$ and GREEA designed this study, managed data collection, and participated in data processing. OOO, OOO and VTF conducted the analyses and were primarily responsible for writing the paper under the supervision of GREEA. All authors contributed to draft manuscripts and the final version. All authors read and approved the final manuscript.

\section{Author details}

${ }^{1}$ Department of Environmental Management and Toxicology, Federal University of Agriculture, Abeokuta, Ogun State, Nigeria. ${ }^{2}$ Department of Environmental Health Sciences, Faculty of Public Health, College of Medicine, University of Ibadan, Ibadan, Nigeria.

\section{Acknowledgements}

We want to thank all respondents who participated in this study. We are grateful to the University of Ibadan who provided official approval for this study.

\section{Competing interests}

The authors declare that they have no competing interests.

\section{Funding}

This research is supported by funding from the Department for International Development (DfID) under the Climate Impact Research Capacity and Leadership Enhancement (CIRCLE) programme.

Received: 26 April 2016 Accepted: 6 September 2016

Published online: 13 September 2016

\section{References}

Abuzant O, Rahha B, Hanbali M, Sinnokrot R (2015) The influence of working in charcoal factories on selected respiratory parameters. An-Najah Univ J Res (Nat Sci) 29(1):59-72

Adewole OO, Desalu OO, Nwogu KC, Adewole TO, Erhabor GE (2013) Respiratory symptoms and lung function pattern in workers exposed to wood smoke and cooking oil fumes (Mai Suya) in Nigeria. Ann Med Health Sci Res 3(1):38-42

Adoki A (2012) Air Quality Survey of some locations in the Niger Delta Area. J Appl Sci Environ Manag 16(1):125-134

Akande JM, Ajaka EO, Omosogbe FM, Lawal Al (2013) Environmental effects of processing marine clay in Olotu, Ondo State, Nigeria. Civ Environ Res 3(2):82-86

Alakija W, Iyaw VI, Jarikre LN, Chiwuzie N (1990) Ventilatory function of workers in a cement factory in Nigeria. West Afr J Med 9:187-192

Anon (2011) What is in wood smoke and solid fuel emission burning issues. Clean Air Revival Inc. www.burningissues. org/smoke.htm

Barone-Adesi F, Chapman RS, Silverman DT, He X, Hu W, Vermeulen R, Ning B, Fraumeni JF, Rothman N, Lan Q (2012) Risk of lung cancer associated with domestic use of coal in Xuanwei, China: retrospective cohort study. BMJ 345:e5414. doi:10.1136/bmj.e5414

Bruce N, Perez-Padilla R, Albalak R (2000) Indoor air pollution in developing countries: a major environmental and public health challenge. Bull World Health Org 78:1080-1092

Colledge NR, Walker BR, Ralston SH (2010) Davidson's principles and practice of medicine, 21st edn. Churchill Livingstone, Edinburgh

Dost FN (1991) Acute toxicology of components of vegetation smoke. Rev Environ Contam Toxicol 119:1-46

Ediagbonya TF, Tobin AE (2013) Air pollution and respiratory morbidity in an urban area of Nigeria. Greener J Environ Manag Pub Saf 2(1):010-015

Edokpa DA, Ikelegbe $\mathrm{OO}$ (2012) Ambient air quality and human health in oil producing rural communities of Edo State. In: Nigerian Meteorological Society (NMetS) conference proceedings of the 2012. Theme: climate change and variability: saving our tomorrow today, pp 180-185

Ellegard A (1994) Health effects of charcoal production from earth kilns in Chisamba area, Zambia. Stockholm Environment Institute, Stockholm, pp 1-16

Ezzati M, Kammen DM (2001a) Indoor air pollution from biomass combustion as a risk factor for acute respiratory infections in Kenya: an exposure-response study. Lancet 358:619-624

Ezzati M, Kammen DM (2001b) Quantifying the effects of exposure to indoor air pollution from biomass combustion on acute respiratory infections in developing countries. Environ Health Persp 109:481-488

Ezzati M, Mbinda BM, Kammen DM (2000) Comparison of emissions and residential exposure from traditional and improved biofuel stoves in rural Kenya. Environ Sci Technol 34:578-583

Federal Environmental Protection Agency (FEPA) (1999) National policy on the environment. The Presidency, Abuja

Fullerton DG, Semple S, Kalambo F, Suseno A, Malamba R, Henderson G, Ayres JG, Gordon SB (2009) Biomass fuel use and indoor air pollution in homes in Malawi. Occup Environ Med 66:777-783

Gardner ZS, Ruppel GL, Kaminsky DA (2011) Grading the severity of obstruction in mixed obstructive-restrictive lung disease. Chest 140(3):598-603

Gauderman W (2004) The effect of air pollution on lung development from 10 to 18 years of age. N Engl J Med 351:1057-1067

Ghosh S, Pal AK, Saxena NC (1996) Impact of road way traffic and transport on human health: energy Environ. Monitor 12:101-107

Gong H (1992) Health effects of air pollution: a review of clinical studies. Clin Chest Med 13:201-214 
Hoek G, Brunekreef B, Goldbohm S, Fischer P, van den Brandt PA (2002) Association between mortality and indicators of traffic-related air pollution in the Netherlands: a cohort study. Lancet 1-7. http://image.thelancet.com/ extras/01art7366web.pdf

Holguin F (2012) The metabolic syndrome as a risk factor for lung function decline. Am J Respir Crit Care Med 185(4):352-353

Ibhazehiebo K, Dimkpa U, Uche OK, lyawe VI (2007) Peak expiratory flow rate and respiratory symptoms following chronic domestic wood smoke exposure in women in Edo, Nigeria. Afr J Biomed Res 10(2007):33-39

Ingle ST, Pachpande BG, Wagh ND, Patel VS, Attarde SB (2005) Exposure to vehicular pollution and respiratory impairment of traffic policemen in Jalgaon City, India. Ind Health 43:656-662

International Agency for Research on Cancer (1997) IARC monographs on the evaluation of the carcinogenic risk of chemicals to human: silica and some silicates. International Agency for Research on Cancer, Lyon

Keraka M, Ochieng C, Engelbrecht J, Hongoro C (2013) Association between the use of biomass fuels on respiratory health of workers in food catering enterprises in Nairobi Kenya. Pan Afr Med J 15:12

Kurmi OP, Lam KBH, Ayres JG (2012) Indoor air pollution and the lung in low- and medium-income countries. Eur Respir J 40:239-254

Longo D, Fauci A, Kasper D, Hauser S, Jameson J, Loscalzo J (2011) Harrison's principles of internal medicine, 18th edn. McGraw-Hill Professional, New York

McConnell R, Shen E, Gilliland FD, Jerrett M, Wolch J, Chang C, Lurmann F, Berhane K (2014) A longitudinal cohort study of body mass index and childhood exposure to secondhand tobacco smoke and air pollution: the Southern California Children's Health Study. Environ Health Perspect. doi:10.1289/ehp.1307031

Miller MR, Hankinson J, Brusasco V, Burgos F, Casaburi R, Coates A, Crapo R, Enright P, van der Grinten CPM, Gustafsson P, Jensen R, Johnson DC, Maclntyre N, McKay R, Navajas D, Pedersen OF, Pellegrino R, Viegi G, Wanger J (2005) Standardisation of spirometry. Eur Respir J 26(2):319-338

Mishra V, Retherford RD (2007) Does biofuel smoke contribute to anaemia and stunting in early childhood? Int J Epidemiol 36:117-129

National Obesity Observatory (NOO) (2009) Body mass index as a measure of obesity. Association of Public Health Observatories

Nelson LS, Hoffman RS (2010) Carbon monoxide. Rosen's emergency medicine: concepts and clinical practice, 7th edn. Marx J, Hockberger R, Walls R (eds). MOSBY Elsevier, Philadelphia, pp 2037-2038

Ogunsanwo OY, Aiyeloja AA, Uzo C (2007) Production techniques and the influence of wood species on the properties of charcoal in Nigeria, a case study of Oyo State. Agric J 2(1):131-133

Orozco-Levi M, Garcia-Aymerich J, Villar J, Ramirez-Sarmiento A, Anto JM, Gea J (2006) Wood smoke exposure and risk of chronic obstructive pulmonary disease. Eur Respir J 27(3):542-546

Po JYT, FitzGerald JM, Carlsten C (2011) Respiratory disease associated with solid biomass fuel exposure in rural women and children: systematic review and meta-analysis. Thorax 66:232-239

Quadrelli S, Bosio M, Salvado A, Chertcoff J (2007) Accuracy of spirometry in the diagnosis of pulmonary restriction. Med Aires 67(6):685

Quanjer PH, Lebowitz MD, Gregg I, Miller MR, Pedersen OF (1997) Peak expiratory flow: conclusions and recommendations of a Working Party of the European Respiratory Society. Eur Respir J 10(Suppl. 24):2s-8s

Raghu G, Collard HR, Egan JJ, Martinez FJ, Behr J, Brown KK et al (2011) An official ATS/ERS/JRS/ALAT statement: idiopathic pulmonary fibrosis: evidence-based guidelines for diagnosis and management. Am J Respir Crit Care Med 183(6):788-824

Rao CM (1995) Effects of smoke condensate on the physiological integrity and morphology of organ cultured rat lenses. Curr Eye Res 14(4):295-301

Schwartz J, Dockery DW (1992) Increased Mortality in Philadelphia associated with daily air pollutions concentrations. Am Rev Respir Dis 145:600-604

Seck G (1991) Peak expiratory flow in 542 Senegalese children and adolescents. Dakar Med 36(2):112-119

Sen S, Peltz C, Beard J, Zeno B (2010) Recurrent carbon monoxide poisoning from cigarette smoking. Am J Med Sci 340:427-428

Shochat GN, Luchessi M (2013) Carbon monoxide toxicity clinical presentation. Medscape. http://emedicine.medscape. com/article/819987-clinical. Accessed: 21 July 2013

Souza MS, Magnarelli GG, Rovedatti MG, Santa Cruz S, Pechen De D'Angelo AM (2005) Prenatal exposure to pesticides: analysis of human placental acetylcholinesterase, glutathione $S$-transferase and catalase as biomarkers of effect. Biomarkers 10:376-389

Sunyer J, Saez M, Murillo C, Castellsague J, Martinez F, Anto JM (1993) Air pollution and emergency room admissions for chronic obstructive pulmonary disease: a 5-year study. Am J Epidemiol 137:701-705

Svedahl S, Svendsen K, Qvenild T, Sjaastad AK, Hilt B (2009) Short term exposure to cooking fumes and pulmonary function. J Occup Med Toxicol 4:9. doi:10.1186/1745-6673-4-9. http://www.occupmed.com/content/4/1/9

Swiston JR, Davidson W, Attridge S, Li GT, Brauer M, van Eeden SF (2008) Wood smoke exposure induces a pulmonary and systemic inflammatory response in firefighters. Eur Respir J 32(1):129-138 
Tunde AM, Adeleke EA, Adeniyi EE (2013) Impact of charcoal production on the sustainable development of Asa Local Government Area, Kwara State, Nigeria. Int Multidiscip J Ethiop 7(2):1-15

Tzanakis N, Kallergis K, Bouros DE, Samiou MF, Siafakas NM (2001) Short-term effects of wood smoke exposure on the respiratory system among charcoal production workers. Chest 119(4):1260-1265

USEPA (2006) Guideline for reporting of daily air quality —air quality index (AQI). Office of Air Quality Planning and Standards, US Environmental Protection Agency

Van Meter KW (2010) Carbon monoxide poisoning. In: Tintinalli JE, Kelen GD, Stapczynski JS (eds) Emergency medicine: a comprehensive study guide, 6th edn. McGraw-Hill, New York, pp 1238-1241

Varon J, Marik PE, Fromm RE, Gueler A (1999) Carbon monoxide poisoning: a review for clinicians. J Emerg Med 17:87-93

Ward DE (1999) Smoke from wildland fires. In: Health guidelines for vegetation fire events, Lima, Peru, 6-9 October 1998, Background papers. WHO, Singapore

WHO (2006) Air quality guidelines for particulate matter, ozone, nitrogen dioxide and sulfur dioxide. Global update 2005. Summary of risk assessment. World Health Organization http://www.who.int/phe/health_topics/outdoorair_aqg/ en/index.html

World Health Organization (1999) Environmental health criteria 213: carbon monoxide, 2nd edn. World Health Organization, Geneva

\section{Submit your manuscript to a SpringerOpen ${ }^{\circ}$ journal and benefit from:}

- Convenient online submission

\section{- Rigorous peer review}

- Immediate publication on acceptance

- Open access: articles freely available online

- High visibility within the field

- Retaining the copyright to your article

Submit your next manuscript at $>$ springeropen.com 